ROCZNIKI TEOLOGICZNE

Tom LXIX, zeszyt $1-2022$

DOI: https://doi.org/10.18290/rt22691-7

\title{
OŁEKSIJ KRAWCZUK
}

IWAN OSTASZCZUK

\section{OBRAZ SĄDU OSTATECZNEGO W IKONOSFERZE SĄDOWNICTWA}

\author{
THE PICTURE OF THE FINAL JUDGMENT \\ IN ICONOSPHERE OF THE JUDICIARY
}

\begin{abstract}
A b s tract. The main function of judicial themes in art is the representation of justice. This article examines the problem of the dialogue of law, religion and art on the example of the image of the Last Judgment, which represents the idea of higher justice, sanctioned by God as the Supreme Judge. On the basis of comparative-historical, semiotic and hermeneutic methods, the question of the genesis and essence of the Christian idea of the Last Judgment was singled out on the basis of narratives of Egyptian and ancient Greek myths and texts of the Holy Scriptures. The main images and symbols of this plot are studied, namely: Christ the Judge, St. Michael, libra and psychostasis. Examples of the Last Judgment in church iconography and art are given.
\end{abstract}

Keywords: the Last Judgment; Christ the Judge; iconosphere of the judiciary; judicial symbolism.

Instytucja sądu jest ważna nie tylko w zakresie państwa, ale także w historii Kościoła i sztuki, gdzie liczne opowieści o sędziach i narracja o sprawowaniu sądownictwa są dość rozpowszechnione w głoszeniu sprawiedliwości sankcjonowanej przez Boga oraz poprzez obecność dzieł sztuki w siedzibach sądowych i urzędach państwowych. Wśród tych tematów w kulturze chrze-

Docent dr hab. OŁEKSIJ KRAwCZuK - sędzia Najwyższego Sądu Antykorupcyjnego (Ukraina, Kijów); profesor Katedry Prawa Informacyjnego, Gospodarczego i Administracyjnego, Narodowy Uniwersytet Techniczny Ukrainy „Kijowski Instytut Politechniczny imienia Igora Sikorskiego” (Ukraina, Kijów); adres do korespondencji: prospekt Peremohy 41, 03057 Ukraina, Kijów; e-mail: kravchuk.kpi@gmail.com; ORCID: https://orcid.org/0000-0002-7844-2381.

Prof. dr hab. IwAN OSTASZCZUK - profesor Katedry Teologii i Religioznawstwa, Narodowy Uniwersytet Pedagogiczny imienia M.P. Dragomanowa (Ukraina, Kijów); adres do korespondencji: ul. Turhenevska 8-14,01054 Ukraina, Kijów; e-mail: ostaszczuk@ukr.net; ORCID: https://orcid.org/0000-0002-6115-0884. 
ścijańskiej szczególne miejsce zajmuje Sąd Ostateczny we właściwych sobie interpretacjach w teologii, głoszeniu w homilii i przedstawieniach w sztuce zarówno obecnych w przestrzeni świątyń, jak i w budynkach władzy publicznej, zwłaszcza w salach sądowych.

Integralnym elementem chrześcijaństwa jest eschatologia jako system wyobrażeń i wierzeń o końcu świata. Obraz Sądu Ostatecznego wyraża przekonanie, że Chrystus będzie sądził wszystkich ludzi, oddzielając sprawiedliwych (dla nagrody) od grzeszników (przeznaczonych na wieczną karę). W katolickiej Europie przedstawienie Chrystusa jako Sędziego i Władcy było popularne i szeroko rozpowszechnione na obrazach Sądu Ostatecznego, co miało ogromny wpływ nie tylko na rozumienie przez średniowiecznego człowieka pojęć grzechu i sądu, ale także na życie społeczne, w szczególności w polityce. Ikonograficzny obraz Jezusa Chrystusa jako Króla i Władcy wszechświata - zdaniem Johna F. O'Gradiego - determinował ,poczucie prawa i władzy, które zaowocowało autorytarnym Kościołem późnego średniowiecza. Jeżeli Jezus rządzi wszystkimi narodami, a Kościół ma udział w Jego autorytecie, to nakłada na Kościół obowiązek absolutnej władzy nad światem. W związku z tym Kościół ma prawo zabronić jakiegokolwiek sposobu myślenia innego niż jego oficjalne nauczanie" stusa jako władcy i sędziego ma podstawy ewangeliczne (J 5,22²; Mt 28,18 ${ }^{3}$ ), to jednak nacisk na ten aspekt miał wyraźny wpływ na rozumienie władzy w społeczeństwie i dążenie Kościoła do supremacji względem świeckiego państwa ${ }^{4}$. Niejako konsekwencją tego pozostają konflikty między papieżem a monarchami, lokalnymi biskupami i feudalną arystokracją poszczególnych krajów, dotyczące zrozumienia granic sprawowanej władzy.

Celem artykułu jest ukazanie obrazu Sądu Ostatecznego w ikonosferze sądownictwa. W tym celu zaprezentowana zostanie geneza chrześcijańskiej idei Sądu Ostatecznego. Przybliżone zostaną ponadto główne obrazy i symbole sądownictwa. Dzięki temu zostanie określone, czym jest i jakie zadanie posiada koncepcja Sądu Ostatecznego w chrześcijaństwie i aksjologii prawa, a także w wymiarze edukacyjnym wyposażenia siedzib sądu. Artykuł przedstawi także kluczową symbolikę pojawiającą się w ikonografii w analizowanym przedmiocie badań. W podsumowaniu artykułu zebrane zostaną wnioski.

\footnotetext{
${ }^{1}$ Джон Ф. О’Грейді, «Современное состояние христологии», w: Современное католическое богословие. Хрестоматия; пер. с англ. (Москва: ББИ св. апостола Андрея, 2007), 226-227.

2 „Ojciec bowiem nie sądzi nikogo, lecz cały sąd przekazał Synowi” (J 5,22).

3 „Wtedy Jezus podszedł do nich i przemówił tymi słowami: «Dana Mi jest wszelka władza w niebie i na ziemi»" (Mt 28,18).

${ }^{4}$ О'Грейді, «Современное состояние христологии», 227.
} 
W artykule zastosowano metodę porównawczo-historyczną (porównanie rozumienia obrazu Sądu Ostatecznego w różnych epokach historycznych), semiotyczną (ujawnianie semantyki poszczególnych symboli) i hermeneutyczną (interpretacja fragmentów ksiąg biblijnych oraz innych tekstów).

\section{GENEZA IDEI SĄDU OSTATECZNEGO}

W genezie niektórych obrazów i elementów symbolicznych chrześcijańskiego wyobrażenia o Sądzie Ostatecznym należy odnieść się do tych kultur, które poprzedzały cywilizację chrześcijańską, a także do tekstów Biblii. Sąd boga Ozyrysa w mitach i symbolice egipskiej miał silny wpływ na chrześcijańską ideę Sądu Ostatecznego. Jednak w chrześcijańskim poglądzie na sąd po śmierci nie ma miejsca na samousprawiedliwienie i własną obronę, jak przedstawione zostało to w egipskiej Księdze Umarlych. Chrześcijanie liczą raczej na miłosierdzie Boże i wstawiennictwo Maryi oraz świętych. Mimo tego kanon ikonografii sądu Ozyrysa wywarł duży wpływ na sztukę europejską. Można zauważyć, że interpretacja sądu w Piśmie Świętym korespondowała z ogólnymi paradygmatami światopoglądowymi starożytności w procesie kształtowania narracji biblijnej:

określenie praktyki sądowniczej jako szczególnie ważnego elementu instytucjonalno-prawnego i społeczno-kulturowego w biblijnej opowieści wiąże się bezpośrednio z faktem, że sądownictwo zostało uznane za obdarzone tą samą boską zasadą, co władza królewska, wykonawcza, ona była uważana równą tej władzy. Jest jasne, że takie postawy ideologiczne okazały się najściślej związane z ewolucją sprawiedliwości w tradycji judeochrześcijańskiej ${ }^{5}$.

Nie bez znaczenia dla chrześcijańskiej koncepcji sądu pozostają koncepcje starożytnej Grecji. Władza królewska i sądownicza koncentrowały się tam w jednej osobie. Według epickich dzieł Homera, ,uprawnienia sądownicze były wyłącznym przywilejem basileusów [...] Właśnie dlatego w poematach często królom dodawane są określenia - «strażnicy sprawiedliwości», «sędziowie»" dy, która nie tylko niesie w sobie znaczenie mądrości rozstrzygania, ale jest

\footnotetext{
${ }^{5}$ Галина Власова, Легитимация институтов публичной власти в политико-правовом и социокультурном измерениях (на примере эволюции правосудия). Автореф. дисс. ... д. ю.н. (Ростов-на-Дону, 2009), 20.

6 Лариса Пальцева, „Судебные институты архаической Греции”, Мнемон. Исследования и публикации по истории античного мира 7(2008): 86.
} 
także uosobieniem mądrości jako takiej. Jest to związane z funkcją bogini, która zgodnie z przekazem mitologii doradzała Zeusowi.

Należy zauważyć, że chrześcijańska koncepcja życia wiecznego, która szczególnie definiowała świadomość człowieka w średniowieczu, była bezpośrednio związana z eschatologicznym wątkiem o końcu świata i Sądzie Ostatecznym - obrazie najwyższej sprawiedliwości, której nikt nie może uniknąć:

W mitologii egipskiej znany jest motyw ważenia na wadze podczas pozagrobowego sądu dobrych i złych uczynków człowieka przed obliczem Ozyrysa (por. w ikonografii zachodnioeuropejskiej Sąd Ostateczny z postacią trzymającego wagę Michała Archanioła). W tradycji starotestamentowej rozwinęła się idea „dnia Jahwe” - całkowitego i ostatecznego triumfu Jahwe nad jego wrogami na ziemi (por. Iz 13,2-9; Ez 30,3 i in.). W miarę wzrostu zainteresowań eschatologicznych (co odzwierciedla m.in. starotestamentowa Księga Daniela - II wiek przed Chrystusem) i szerzenia wiary w zmartwychwstanie umarłych, „dzień Jahwe" jest coraz częściej rozumiany jako Sąd Ostateczny. Teksty Nowego Testamentu wielokrotnie opisują, często w formie alegorycznej, ostateczne oddzielenie ludzi złych od dobrych („,chwast” od „pszenicy”, „owce” od „kozłów”, Mt 13,$30 ; 25,32-33$ i in.). Wspomniane jest eschatologiczne przyjście „Syna Człowieczego" z orszakiem ,aniołów z trąbą o głosie potężnym” (Mt 24,30-31) [...] W obecności wszystkich aniołów Sędzia zasiądzie na tronie, przed którym zgromadzą się ,wszystkie narody” (Mt 25, 31-32), i odbędzie się sąd: usprawiedliwieni staną po prawej stronie Sędziego (szczęśliwa strona), skazani - po lewej (Mt 25,34-46) . $^{2}$

Chcąc zrozumieć chrześcijańską narrację o końcu świata i rozliczeniu za czyny ludzi należy sięgnąć do biblijnych tekstów, które koncentrują się na przedstawieniu kosmicznej katastrofy. W założeniu autorów ma ona oznaczać koniec świata i w konsekwencji towarzyszyć będzie Sądowi Ostatecznemu. Wtedy to, jak podkreślają autorzy biblijni, „gwiazdy i moce niebios zostaną wstrząśnięte, samo niebo zostanie usunięte jak księga, którą się

${ }^{7}$ „Wówczas ukaże się na niebie znak Syna Człowieczego i wtedy będą narzekać wszystkie narody ziemi; i ujrzą Syna Człowieczego, przychodzącego na obłokach niebieskich z wielką mocą i chwałą. Pośle On swoich aniołów z trąbą o głosie potężnym i zgromadzą Jego wybranych z czterech stron świata, od jednego krańca nieba, aż do drugiego" (Mt 24,30-31).

${ }^{8}$ „Gdy Syn Człowieczy przyjdzie w swej chwale i wszyscy aniołowie z Nim, wtedy zasiądzie na swoim tronie pełnym chwały. I zgromadzą się przed Nim wszystkie narody, a On oddzieli jednych [ludzi] od drugich, jak pasterz oddziela owce od kozłów. Owce postawi po prawej, a kozły po swojej lewej stronie [...], I підуть ті на вічне покарання, а праведники - на життя вічне» [...] I pójdą ci na mękę wieczną, sprawiedliwi zaś do życia wiecznego" (Mt 25,31-33,46); Мифологический словарь (Москва: Сов. Энциклопедия, 1990), 502. 
zwija (Mt 24,29 i Ap 6,12-14) , od tronu Sędziego strumień ognia się rozleje (Dn 7,10)" " Przywołana Księga Daniela zawiera ponadto fragment o tajemniczych napisach przeznaczonych dla ostatniego chaldejskiego władcy Babilonu, tzn. Baltazara. Kluczowe wydarzenia miały miejsce podczas wystawnej uczty. W jej trakcie władca wraz z dworzanami używali naczyń liturgicznych, które Nabuchodonozor przywiózł ze świątyni w Jerozolimie (Dn 5,1-4).

I w tej chwili ukazały się palce ręki ludzkiej i pisały za świecznikiem na wapnie ściany królewskiego pałacu. Król zaś widział piszącą rękę. Twarz króla zmieniła się, myśli jego napełniły się przerażeniem, jego stawy biodrowe uległy rozluźnieniu, a kolana jego uderzały jedno o drugie (Dn 5,5-6).

Żaden $\mathrm{z}$ chaldejskich mędrców nie potrafił rozszyfrować tego, co zostało napisane. Za radą matki władca wezwał Daniela, ,jednego z uprowadzonych z Judy". Prorok nie tylko wyjaśnił znaczenie poszczególnych słów, ale dokonał również ich interpretacji, ujawniając tym samym ukryte znaczenie:

A oto nakreślone pismo: mene, mene, tekel ufarsin. Takie zaś jest znaczenie wyrazów: Mene - Bóg obliczył twoje panowanie i ustalił jego kres. Tekel - zważono cię na wadze i okazałeś się zbyt lekki. Peres - twoje królestwo uległo podziałowi; oddano je Medom i Persom (Dn 5,25-28)

i „tej samej nocy król chaldejski Baltazar został zabity” (Dn 5,30).

Interpretując zacytowany fragment biblijny warto podkreślić wymiar władzy Boga nad człowiekiem. Nie tylko zważył on złe czyny Baltazara (w szczególności świętokradcze spożycie wina z naczyń zrabowanych w świątyni jerozolimskiej), ale określił śmierć władcy i koniec panowania jego dynastii. W całym tym fragmencie ,widzimy obraz Boga jako sprawiedliwego sędziego, który umiejętnie zarządza sprawami świata i nie tylko ocenia myśli i czyny, ale także kontroluje losy ludzi"11.

9 „I ujrzałem: gdy otworzył pieczęć szóstą, stało się wielkie trzęsienie ziemi i słońce stało się czarne jak włosienny wór, a cały księżyc stał się jak krew. I gwiazdy spadły z nieba na ziemię, podobnie jak drzewo figowe wstrząsane silnym wiatrem zrzuca na ziemię swe niedojrzałe owoce. Niebo zostało usunięte jak księga, którą się zwija, a każda góra i wyspa z miejsc swych poruszone" (Ap 6,12-14).

${ }^{10}$ Елеазар Мелетинский, гл. ред., Мифологический словарь (Москва: Сов. Энциклопедия, 1990), 502.

11 Лиланд Райкен, и др., ред., Словарь библейских образов; пер. с англ. (Санкт-Петербург: Библия для всех, 2008), 134. 
Podejmując zagadnienie władzy sądzenia, która spoczywa w ręku Boga, warto przyjrzeć się etymologii słowa „sąd” użytego w oryginale greckim Ewangelii. Otóż termin ten znaczeniowo pochodzi od słowa „kryzys” -

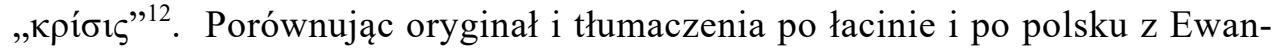
gelii według św. Jana 12,31 można otrzymać interesujące wnioski. Otóż tłumaczenie na język polski: „Teraz odbywa się sąd nad tym światem”13 oraz język łaciński pomijają termin „kryzys” - „крíøıৎ”. Pojawia się natomiast słowo „sąd" stosowane w praktyce świeckiego wymiaru sprawiedliwości: „Nunc iudicium est huius mundi” ${ }^{14}$. We współczesnych językach słowo „kryzys" w polityce, ekonomii, kulturze czy życiu osobistym ma wyraźnie negatywną semantykę. Jednak zupełnie inne znaczenia istniały w starożytności, kiedy powstawał tekst Ewangelii:

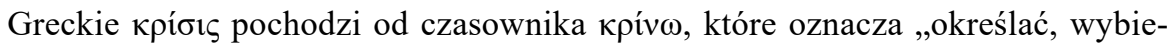
rać". Ten czasownik jest mocno zakorzeniony w praktyce sądowej i oznacza wszystkie czynności procesu sądowego: oskarżenie, prowadzenie procesu sądowego, postępowanie dowodowe, a nawet skazanie, zachowując też ogólne znaczenie „prowadzenie sprawy przed sądami”. W swoim funkcjonowaniu кpírıs zachowuje te znaczenia (sąd, proces sądowy, wyrok), ale także nabywa kilka nowych semantyk: wynik (bitwy), rywalizacja, thumaczenie (snu). Negatywnego

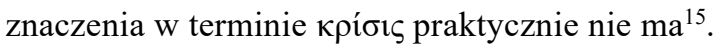

Jak widać, nieustanne kryzysy społeczne, osobiste - widoczne w etymologii tekstu ewangelicznego w określaniu sądu nad światem - pozostają w semantycznej zgodności, jaka pojawia się w praktyce świeckiego wymiaru

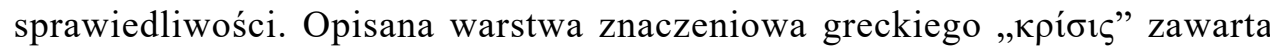
jest bowiem w oryginalnym tekście Ewangelii. Ukazuje to zbieżność sprawowanej władzy sądowniczej, która inspiracje czerpie (w warstwie etymologicznej) z prerogatyw, jakimi w Ewangelii dysponował sam Bóg.

Topos Sądu Ostatecznego staje się zachętą dla twórców sztuki, którzy w kolejnych epokach sięgają do biblijnych inspiracji. Realizację rozstrzygnięć, typowych dla świeckiego wymiaru sprawiedliwości, widać doskonale w średniowiecznych obrazach inspirowanych sceną Sądu Ostatecznego. Otóż

\footnotetext{
${ }^{12}$ Greek-English New Testament (Deutsche Bibelgesellschaft, 1998), 292.

${ }^{13}$ W języku ukraińskim: „Нині настав суд цьому світові”.

${ }^{14}$ Novum Testamentum Latine (Deutsche Bibelgesellschaft, 2002), 292.

${ }^{15}$ Алексей Егоров, „Кризисы в истории Рима (события и проблемы)”, Мнемон. Исследования и публикации по истории античного мира. Сборник статей к 80-летию со дня рождения проф. Э.Д. Фролова 12(2013), 348.
} 
w przywołanych dziełach sztuki nie chodziło o miłosierdzie czy Bożą miłość. Motywem staje się natomast jurysdykcyjne rozliczenie grzesznika. W konsekwencji zostaje on zaliczony do sprawiedliwych bądź podlega karze jako grzesznik ${ }^{16}$.

\subsection{ObRaZ SĄDU OSTATECZNEGo W SZTUCE}

Fabuła Sądu Ostatecznego jest wieloaspektowa i w większości „gęsto zaludniona" przez liczne postacie, a w swej treści wewnętrznej jest filozoficznie syntetyczna i otwarta na różne interpretacje, jakie dokonały się w historii badań światowego malarstwa. W jednym z przykładów wizualizacji sceny Sądu Ostatecznego włoski malarz, przedstawiciel protorenesansu Giotto di Bondone (ok. 1267-1337), zawarł wiele interesujących spostrzeżeń. Na freskach w kaplicy Scrovegnich w Padwie wprowadził on do tradycyjnych tematów z Pisma Świętego i historii Kościoła wyraźne ziemskie tło i kontekst. W całej przestrzeni zachodniej ściany umieścił obraz Sądu Ostatecznego, zgodnie z opisami Apokalipsy i Ewangelii według św. Mateusza. W dziele artysta przedstawił także siebie oraz sobie współczesnych. Wielkoformatowy obraz podzielony jest na trzy części. Majestatyczna postać Chrystusa, jako Sędziego siedzącego na obłoku, znajduje się w mandorli otoczonej serafinami - w górnej środkowej części; prawą stronę (licząc od Zbawiciela) zajmują sprawiedliwi, lewą natomiast grzesznicy. Kompozycyjne oddzielenie usprawiedliwionych i skazanych na potępienie dokonuje się za pomocą wielkiego krzyża, który aniołowie trzymają pod postacią Chrystusa. Po prawej jego stronie płynie rzeka krwi, podzielona na cztery części, wzdłuż której znajdują się skazani na męki piekielne. W pobliżu budzącego wstręt szatana usytuowane są postacie znanych grzeszników, w tym Judasza Iskarioty ${ }^{17}$. Dzieło posiada zatem nie tylko koncepcje zaczerpnięte z Objawienia (podział grzesznych i sprawiedliwych). Zawiera również odautorskie interpretacje, które są przejawem średniowiecznych przekonań, rozumienia treści teologicznych, ale zapewne także intuicyjnego podejścia, które rozwija przesłanie biblijne.

\footnotetext{
${ }^{16}$ Krzysztof Bardski, „Bóg jako sprawiedliwy sędzia w symbolicznej ikonosferze biblijnej starożytności chrześcijańskiej i średniowiecza”. Verbum Vitae 26 (2014): 156, dostęp 10.07.2021, http://cejsh.icm.edu.pl/cejsh/element/bwmeta1.element.desklight-45d01e1e-1d01-4425-90d4-49b 0d4bf0949/c/143_pdfsam_Verbum_26.pdf

17 „La Cappella degli Scrovegni”, dostęp 15.06.2021, http://www.cappelladegliscrovegni.it/ index.php/it/.
} 
Analizowany powyżej element symboliki sądowej w kulturze zachodniej znalazł szerokie zastosowanie w sztuce muzycznej m.in. jako sekwencja łacińska Dies irae („Dzień gniewu”). Przywołany utwór stał się centralną częścią łacińskiego Requiem, który opowiada o Sądzie Ostatecznym i przedstawia lęk grzeszników przed oczekiwanym wyrokiem. Dies irae zinterpretowany został przez wielu artystów. Są wśród nich W.A. Mozart, H. Berlioz, F. Liszt, P. Czajkowski, J. Brahms, G. Verdi, A. Dvořák, S. Rachmaninow, C. Saint-Saëns, D. Szostakowicz oraz K. Penderecki. Takie zainteresowanie jest dowodem popularności tematu, który - zaczerpnięty uprzednio z treści Objawienia - pozwala przywołanym twórcom na rozliczne interpretacje.

\subsection{SĄD OSTATECZNY W IKONOGRAFII UKRAIŃSKIEJ}

Obok wskazanych powyżej inspiracji artystycznych obraz sądu pojawia się także w ukraińskiej ikonografii cerkiewnej. W licznych dziełach, które powstały od XV do XVIII w. można wskazać istniejące związki między pojęciami sądu Bożego i prawa jako takiego:

thumaczy się to podobieństwem interpretacji pojęć „,grzech”, „krzywda” i „przestępstwo" w ówczesnym społeczeństwie. Na ikonach Sądu Ostatecznego najczęściej występują następujące grzechy: czary, nierząd, kradzież, dzieciobójstwo, krzywoprzysięstwo. Uznano je również za przestępstwa. Z każdym nowym okresem rosła zmienność „grzechów”, podobnie jak rodzaje przestępstw w ustawodawstwie. Dlatego system prawny i ikonografia miały wzajemny wpływ. Jedną $\mathrm{z}$ centralnych kategorii świadomości prawnej od XV w. był pokój, który ustanowił Bóg. Społeczne wyobrażenie o naturze sądu i sąd Boży były łączone przez ideały sprawiedliwości, a odstępstwa od tego ideału były rozumiane jako rozmaite nadużycia sądowe ${ }^{18}$.

Początkowo sądy wszystkich narodów odbywały się „w imieniu Boga, a dopiero potem - króla, księcia, narodu itd." "'. W starożytności człowiek mierzył wolą bogów (lub jedynego Boga) nie tylko sprawiedliwy sąd, ale także system wartości, normy etyczne czy legitymizację władzy.

W ukraińskiej ikonografii chrześcijańskiej bardzo popularny jest obraz Michała Archanioła, co w szczególności wiąże się z przypomnieniem o wyższej sprawiedliwości Sądu Ostatecznego. Przywódca sił anielskich przedsta-

\footnotetext{
${ }^{18}$ Анастасія Григорак, Світоглядні орієнтири українського соціуму у світлі іконографії Страшного суду XV-XVIII ст. Автореф. дисерт. ... к. іст. н. (Київ, 2020), 12.

19 Эдуард Георгиевский, „Символизм древнерусского уголовного права”, Право и политика 2(2013): 240.
} 
wiany jest jako groźny i potężny wojownik w rycerskim stroju z mieczem do walki z siłami zła, która będzie trwała do końca świata. Obraz miecza nie jest tutaj przypadkowy - oznacza karę za grzechy niesprawiedliwych. Symbol ten występuje na kartach Biblii jako atrybut Boga - sędziego karającego: „Gdy miecz błyszczący wyostrzę i wyrok wykona ma ręka, na swoich wrogach się pomszczę, odpłacę tym, którzy Mnie nienawidzą. Upoję krwią moje strzały, mój miecz napasie się mięsem, krwią poległych i uprowadzonych, głowami dowódców nieprzyjacielskich" (Pwt 32,41-42). Te wersety z Księgi Powtórzonego Prawa możemy tłumaczyć jako aluzję do obrazu Sądu Ostatecznego $^{20}$.

Ciekawym elementem ukraińskiej symboliki cerkiewnej jest świadome usytuowanie scen Sądu Ostatecznego przy wyjściu z cerkwi. Budzący grozę obraz powinien przypominać chrześcijanom o nieuchronności sprawiedliwego sądu, jaki będzie miał miejsce na końcu świata. Usytuowany bardzo często przy wyjściu ze świątyni obraz miał pozostawiać w pamięci ludzi przesłanie związane $\mathrm{z}$ apokaliptycznym oddzieleniem sprawiedliwych od grzeszników, co będzie miało miejsce u kresu czasów ${ }^{21}$.

W kulturze ukraińskiej z wydarzeniem Sądu Ostatecznego związany jest także miecz kojarzony z oddzieleniem rzeczywistości zła i tego, co w oczach Bożych dobre i sprawiedliwe. Samo odwołanie do broni w symbolice pojawia się już w przedchrześcijańskiej kulturze Słowian. Zamieszkali zwłaszcza w Europie Wschodniej uważali, że miecz ma siłę i moc odcinania tego, co bezowocne i niegodne ${ }^{22}$. Z powyższych spostrzeżeń można sformułować wniosek, że skoro sam symbol miecza był tak popularny, nie może dziwić łatwość jago akomodacji w symbolice chrześcijańskiej. Widać to chociażby na przykładzie św. Michała Archanioła, jaki często pojawia się w symbolice na terenach Rusi Kijowskiej. Przykładem może być herb miasta Kijów.

\footnotetext{
${ }^{20}$ Bardski, „Bóg jako sprawiedliwy sędzia”, 151.

${ }^{21}$ Teolog ojciec Aleksander Mień w jednym ze swoich kazań na temat Sądu Ostatecznego sformułował myśl, która zgadza się z koncepcją, że po nabożeństwie ludzie powinni oglądać obrazy karania grzeszników: „Sąd - po grecku «kryzys». Kryzys, który nadejdzie nie za tysiąc lat, ale który rozpoczął się, gdy Pan przyszedł na ziemię. «Teraz odbywa się sąd nad tym światem» - mówi Pan. Więc dzisiaj [...] Sąd to oczyszczenie naszego sumienia, odrodzenie tego, co ukryte brudem, ziemią, piaskiem z naszej własnej ludzkiej słabości i naszych grzechów". Олександр Мень, Проповіді на церковний рік; пер. з рос. М. Лемик (Львів: Свічадо, 2014), 104.

22 Тамара Губаева, Язык и право. Искусство владения словом в профессиональной юридчческой деятельности, 2-е изд., пересмотр. (Москва: Норма-Инфра-М, 2010), 9.
} 


\section{SYMBOL WAGI. PSYCHOSTAZJA}

Koncepcja Sądu Ostatecznego stała się inspiracją dla artystycznego wyrazu wielu związanych właśnie z sądem atrybutów. Jednym z nich jest waga, która zaczerpnięta $\mathrm{z}$ motywów Objawienia oraz kultur przedchrześcijańskich znalazła swoje stałe miejsce w ikonografice świeckiego wymiaru sprawiedliwości.

Ludy starożytnego Wschodu zaczęły używać obrazu-symbolu wagi na podstawie obserwacji naturalnych zmian przyrody związanych z procesem jesiennej i wiosennej równonocy. Przywołany moment interpretowany był jako symbol przemieniania świata. Jesienne zrównanie dnia z nocą symbolizowało moment śmierci, ponieważ to astronomiczne zjawisko oznaczało początek obumierania natury. Dlatego waga - jej równowaga (przez analogię do praktycznie równości dnia i nocy w tym okresie roku) przypominała o śmierci człowieka i nieuniknięciu odpowiedzialności wobec bogów, którzy „zważą”, aby ustalić, na jaki pośmiertny los zasługuje dusza. Idea ta była uniwersalna w starożytnym świecie; to właśnie z tych porównań naturalnych zjawisk astronomicznych $\mathrm{z}$ wagą rodzi się symbol obecny w różnych kulturach i epokach ${ }^{23}$. W starożytnych Indiach waga była obdarzona sakralną funkcją rozróżniania dobrych i złych uczynków ${ }^{24}$. Rzymianie wagę razem z mieczem rozumieli jako symbol sprawiedliwości. Były one atrybutami Merkurego, który oprócz patrona handlu był także sędzią $\mathrm{w}$ zaświatach ${ }^{25}$. Na starożytnych monetach rzymskich można znaleźć wizerunki personifikacji sprawiedliwości trzymającej wagę. W kulturze greckiej ,znane są przedstawienia na wazach, w których Hermes odważa losy Achillesa i Memnona"26. Opisywany symbol pojawia się również $\mathrm{w}$ greckiej mitologii w ręku bogini sprawiedliwości Temidy. Samo wyobrażenie, związane z przywołaną postacią, posiada bardzo bogatą historiografię i należy do najbardziej popularnego motywu związanego z sądownictwem. W artystycznych przedstawieniach Temida nie tylko trzyma w ręku wagę, która jest nośnikiem sprawiedliwości lub niegodziwości ludzkich czynów. Jej oczy zasłania opaska, która symbolizuje bezstronność orzekania. Wato zwrócić także uwagę na miecz, którego znaczenie pozostaje zupełnie obce chrześcijańskiej wizji sądu. Otóż nie jest on symbolem

${ }^{23}$ Dorothea Forstner, Świat symboliki chrześcijańskiej. Leksykon (Warszawa: PAX, 2001), 433-434.

${ }^{24}$ Владимир Адамчик, авт-сост., Словарь символов и знаков (Москва: АСТ; Минск: Харвест, 2006), 19.

${ }^{25}$ Вадим Телицын, ред., Символь, знаки, эмблемы: Энциклопедия (Москва: ЛОКИДПРЕСС: РИПОЛ Классик, 2005), 74.

${ }^{26}$ Forstner, Świat symboliki, 433. 
walki z tym co złe. Identyfikowany jest natomiast jako znak gotowości do zakończenia sporu. Interesujące jest to, że waga jako symbol ma znaczenie w typologii transkulturowej. Pojawia się bowiem w zupełnie obcych względem siebie kulturach antyku ${ }^{27}$.

W kontekście cytowanego już uprzednio tekstu z Księgi Daniela (Dn 5, 25-28) można zwrócić uwagę na jeden szczegół. Tradycyjnie na obrazach Sądu Ostatecznego w centrum znajduje się postać Michała Archanioła. Jego waga pokazuje miarę ciężkości duszy człowieka, który może okazać się grzesznikiem lub sprawiedliwym. U większości artystów zasada jest taka, iż naczynie wagi z grzesznikiem, obciążonym grzechami, opada (niczym w kierunku piekła), a ze sprawiedliwym łatwo unosi się (do królestwa niebieskiego). Przykładem takiej kompozycji jest poliptyk ołtarzowy „Sąd Ostateczny” (1445-1450; Beaune, Francja) autorstwa niderlandzkiego malarza Rogiera van der Weydena. W przypadku flamandzkiego artysty Hansa Memlinga w jego tryptyku „Sąd Ostateczny” (1466-1473) można zaobserwować zupełnie odmienną koncepcję. Otóż w wizji twórcy grzesznik jest podniesiony, a sprawiedliwy zostaje opuszczony. Występującą tutaj różnicę można wytłumaczyć przytoczonym powyżej proroctwem Daniela. Grzechy Baltazara symbolizują jego puste życie, które nie przyniosło żadnych dobrych owoców, co w konsekwencji sprawia, że w oczach Boga jest on lekki. Widać tutaj przeciwstawienie świętości (dobrego życia) wobec bogactwa, lenistwa, nadmiaru i przepychu, które z kolei są nośnikami złej egzystencji na ziemi.

W dydaktyczno-poetyckiej Księdze Przysłów symbolika wagi jest bezpośrednio przywoływana w związku z refleksjami o sprawiedliwości i sądzie: „Na wargach królewskich wyrocznia: jego usta w sądzie nie błądzą. Waga i szala to sprawa Pana, Jego dzieło - ciężarki we worku. Obrzydłe królom działanie nieprawe, bo tron się opiera na sprawiedliwości” (Prz 16,10-12). Obraz wagi w kontekście Sądu Ostatecznego wspomniany jest także w 31. rozdziale Księgi Hioba. W przywołanym tekście autor, który jest człowiekiem sprawiedliwym, wypróbowanym i cierpiącym, wykrzykuje: „Czym chodził do bożyszcz? Czy noga do oszustwa spieszyła? Niech zważy mnie bardzo dokładnie, a pozna, że jestem niewinny" (Hi 31,5-6). Opisywany symbol pojawia się także w księdze proroka Izajasza. Autor natchniony stawia pytanie: „Kto zważył góry na wadze i pagórki na szalach?” (Iz 40,12). W nawiązaniu do tego fragmentu teologowie okresu Średniowiecza widzieli

\footnotetext{
${ }^{27}$ Karol Dobrzeniecki, „Harmonia teologii, prawa i kosmologii na przykładach zastosowania motywu wagi w sztuce czasów przednowożytnych", Teologia i człowiek. Kwartalnik Wydziału Teologicznego UMK 30(2015), 2: 79-80.
} 
aluzję do bezstronności Boga w określaniu winy lub usprawiedliwieniu dusz ludzkich. Góry i pagórki mogą tutaj także symbolizować pychę człowieka. Symbolika wagi sądowej pojawia się również w Psalmach. W jednym z tekstów widzimy obraz wagi, na której dopuszczający się kłamstwa nie posiadają wartości, stając się lekkimi jak powietrze: „Synowie ludzcy są tylko jak tchnienie, synowie mężów - kłamliwi; na wadze w górę się wznoszą: wszyscy razem są lżejsi niż tchnienie" (Ps 62,10) ${ }^{28}$.

Wykorzystywanie symbolu wagi pojawia się także w ikonografii chrześcijańskiej. Zarówno we wschodniej jak i zachodniej tradycji liturgicznej opisywany symbol związany jest z wizją Sądu Ostatecznego ${ }^{29}$. Chrześcijańska myśl artystyczna dotycząca sądu Bożego została oparta na przekonaniu nie tylko sprawiedliwego sądu Boga, w którym Stwórca miał rozstrzygnąć o losie każdej ludzkiej istoty. Zbudowana została także na eschatologicznym motywie Sądu Ostatecznego, gdzie istotnymi elementami była kara, która ma spotkać grzeszników. Ważnym czynnikiem było ponadto ostateczne rozdzielenie sprawiedliwych od ludzi nieprawych ${ }^{30}$. Ikonograficzne przedstawienie symbolu wagi w kulturze chrześcijańskiej jest więc bardzo powszechne i rozpoznawalne, toteż np. gdy w średniowieczu sąd odbywał się w kościele, wizualne symbole przestrzeni sakralnej były w pełni zgodne $\mathrm{z}$ atrybutami procesu sądowego.

Interesujący motyw zachował się w sztuce romańskiej i gotyckiej, otóż ukształtował się tam odrębny topos, przedstawiający ważenie dusz (w postaci nagich ciał lub serc) na wadze - psychostazja (z gr. „ważenie dusz”) ${ }^{31}$. Powszechne rozprzestrzenianie się fabuły Sądu Ostatecznego (popularne także w miniaturach książkowych i ołtarzowych obrazach), w szczególności $\mathrm{z}$ symbolem wagi, wiązało się nie tylko $\mathrm{z}$ teocentrycznym paradygmatem kulturowym średniowiecza, ale także $\mathrm{z}$ systematycznym rozwojem prawa oraz kształtowaniem nowych procedur sądowych obecnych w życiu spo$ł_{\text {łecznym }}^{32}$. Można zauważyć, że sama forma symbolu wagi zawiera $\mathrm{w}$ sobie także wbudowaną ideę równowagi i symetrii. Oznacza to z kolei, że każda wina, zbrodnia nieuchronnie uaktywniają w świecie siły, które w tym życiu mogą prowadzić do otrzymania przez niesprawiedliwego należnej mu kary ${ }^{33}$.

\footnotetext{
${ }^{28}$ Bardski, „Bóg jako sprawiedliwy sędzia”, 147-148.

${ }^{29}$ Forstner, Świat symboliki, 434.

${ }^{30}$ Bardski, „Bóg jako sprawiedliwy sędzia”, 156.

${ }^{31}$ Llewellyn Howes, „Who Will Put My Soul on the Scale?: Psychostasia in Second Temple Judaism”, Old Testament Essays, 27(2014), 1: 100.

32 Арон Гуревич, Избранные труды. Культура средневековой Европы (Санкт-Петербург: Изд-во С.-Петербургского у-та, 2006), 369.

${ }^{33}$ Адамчик, Словарь символов и знаков, 19.
} 
Rozwój świeckich struktur władzy sądowniczej ma swoje reminiscencje w sztuce sakralnej, co związane jest z wizją Chrystusa - Sędziego. Nad wejściem do prawosławnego Soboru (katedry) św. Włodzimierza w Kijowie można zobaczyć wizerunek Chrystusa Sędziego z krzyżem w prawej ręce i otwartą księgą życia w lewej. Po prawej stronie Najwyższego Sędziego Matka Boża schyliła głowę na ramieniu Syna, po lewej - klęczący Jan Chrzciciel, poniżej symbole czterech ewangelistów (anioł, orzeł, lew i byk) otoczonych mnóstwem aniołów i świętych. Matka Boża, według ikonologii prawosławnej, prosi swojego Syna Jezusa Chrystusa, aby był miłosiernym sędzią nad grzesznymi ludźmi. Czarno-czerwone tło obrazu symbolizuje strach i podziw grzeszników. Autor - artysta Wiktor Wasniecow (1848-1926) - w dolnej części fresku przedstawił surowego anioła w stroju diakona, $\mathrm{z}$ zapieczętowanym zwojem księgi (ze spisem grzechów) trzymającego w lewej ręce wagę. Zgodnie z tradycją prawosławnego kanonu ikonograficznego (chociaż wszystkie postacie przedstawione są realistycznie w stylu malarstwa zachodniego), scena Sądu Ostatecznego ukazuje również węża-diabła i grzeszników, którzy znajdują się w lewej dolnej części fresku. Przedstawieni na wizerunku są także ludzie sprawiedliwi. Znajdują się oni nie tylko po przeciwnej stronie względem ludzi nieprawych. Wyróżnia ich ponadto radosne spojrzenie, które kierują ku niebu.

Wyobrażenia związane $\mathrm{z}$ władzą sądowniczą pojawiają się nie tylko w twórczości ikonograficznej lub powstających obrazach. Obok obrazu sprawiedliwego sądu (alegoria wagi) pojawia się także w sztuce scenicznej interesujący motyw upersonifikowanej ludzkiej mądrości, która służy sprawiedliwemu werdyktowi. We Lwowskiej Operze Narodowej od 1901 roku scenę zdobi kurtyna „Parnas” Henryka Siemiradzkiego (1843-1902) - genialnego twórcy kompozycji inspirowanych mitologią oraz okresem wczesnochrześcijańskim. Współczesny odbiorca ma okazję zobaczyć jego wielkoformatowy obraz podczas premier spektakli operowych i baletowych. W centrum obrazu ukazane są alegorie kluczowych myśli artysty: „Przed ołtarzem Sztuki, pośrodku, jako główna postać kompozycji przedstawione jest Natchnienie, będące źródłem twórczości. Przed nim, powstająca z dymów, wzlatuje uskrzydlona Wyobraźnia, którą stara się powstrzymać ukazana w zbroi Minerwa, będąca wcieleniem Rozumu"34. Przywołany motyw wydaje się kluczowy. Jest tak dlatego, że właśnie alegoria Rozumu, trzymającego wagę w lewej ręce, jednocześnie drugą dłonią wskazuje na równoważenie intuicyj-

${ }^{34}$ Igor Chomyn, 150 arcydzieł malarstwa polskiego ze zbiorów Lwowskiej Galerii Sztuki (Pelplin: Bernardinum, 2006), 66. 
nego natchnienia i niepowstrzymanej wyobraźni. Rozum i racjonalność są więc ważnymi fundamentami nie tylko sporów sądowych, ale także twórczości. Siemiradzki pośrednio wskazywał na inny aspekt relacji między sądem a sztuką. Otóż dzieła sztuki również podlegają „sądowi”. Chodzi tutaj o krytykę, która często determinuje niezapomniane miejsce utworu w historii lub rozstrzyga o jego bezpowrotnym zapomnieniu.

\section{CHRYSTUS SĘDZIA. TRADITIO LEGIS}

Obok wskazanych już powyżej rozstrzygnięć, warto ocenić niektóre z treści Objawienia, które same w sobie przypominają rozprawę sądową, w której audytorem jest Jezus Chrystus. Można powiedzieć, że „Apokalipsa to zbiór wizji, z których każda ujawnia tę lub inną stronę, albo szczegół rzeczywiście prowadzonego procesu sądowego"35. Obraz Chrystusa Prawodawcy ukształtował się i rozpowszechnił w obrazie Traditio legis (,przekazywanie prawa”), w którym Jezus daje apostołowi Piotrowi zwój z tekstem. W ten sposób Chrystus afirmuje niejako sukcesję apostolską. Wyraża to także świeckie rozumienie inwestytury. Jej znaczenie, zorganizowane według królewskiego protokołu, miało być równe religijnej wymowie z misją, której udziela właściwa władza kościelna ${ }^{36}$. W jednym $\mathrm{z}$ gotyckich tympanonów można odnaleźć następującą inspirację:

W opactwie Saint-Pierre de Moissac (Tarn-et-Garonne) majestatyczny i surowy Chrystus zajmuje niemal całą przestrzeń lunetową na szczycie portalu południowego. Otaczają go symbole ewangelistów, a także para aniołów i 24 starców Apokalipsy, umieszczonych $\mathrm{w}$ trzech rejestrach (czyli na trzech poziomach wysokości), które dosłownie cytują Objawienie Jana. Temat Sądu Ostatecznego i końca świata jest przedstawiony w rzeźbiarskich płaskorzeźbach wzdłuż lewej krawędzi portyku, gdzie górny rejestr odtwarza przypowieść o bogaczu i Łazarzu, a poniżej pokazuje, jak cierpią nieszczęsne dusze grzeszników ${ }^{37}$.

\footnotetext{
${ }^{35}$ Бальтазар Ганс Урс фон Бальтазар, „Суды Божии в Откровении Иоанна Богослова”, Символ Paris 16(1986): 15.

${ }^{36}$ Умберто Еко, ред., Історія європейської иивілізаиії. Середньовіччя. Варвари. Християни. Мусульмани; пер. з італ. (Харків: Фоліо, 2018), 607.

37 Умберто Еко, ред., Історія європейської ичивілізаиії. Середньовіччя. Собори. Лицарі. Міста; пер. $з$ італ. (Харків: Фоліо, 2018), 503.
} 
Ten wątek rozprzestrzenił się we wszystkich krajach Europy Zachodniej. Można zauważyć, że takie obrazy powstały z inspiracji, iż Sąd Ostateczny będzie sprawiedliwy i bezlitosny oraz tego, że przed jego jurysdykcją nic nie może się ukryć. Przytoczone inspiracje widać także w liturgii Kościoła. Przykładowo do reformy liturgicznej Soboru Watykańskiego II piąta Niedziela Wielkiego Postu była nazywana Judica. Inspiracją do stosowania tej nazwy był wykonywany na początku Mszy Świętej łaciński tekst Psalmu 43. Jego pierwsze słowa brzmią - Judica me, Deus ${ }^{38}$ - „Wymierz mi, Boże, sprawiedliwość i broń mojej sprawy przeciw ludowi, co nie zna litości; wybaw mnie od człowieka podstępnego i niegodziwego! Przecież Ty jesteś Bogiem mej ucieczki, dlaczego mnie odrzuciłeś? Czemu chodzę smutny gnębiony przez wroga?" (Ps 43,1-2). W artystycznym wykonaniu zacytowanego Psalmu, na dwa tygodnie przed Wielkanocą, przypominano zatem charakter sądu Bożego. Zgodnie z przesłaniem liturgicznym będzie to wydarzenie nacechowane surowością, gdzie każdego z ludzi spotka sprawiedliwy wyrok.

\section{MICHAŁ ARCHANIOE \\ W IKONOGRAFII SĄDU OSTATECZNEGO}

Inspiracja Chrystusa - Sędziego ma swoje rozwinięcie w sztuce sakralnej. Są nimi chociażby wyobrażenia Michała Archanioła. Waga w jego ręku wskazywała na los duszy człowieka w wieczności ${ }^{39}$. Od pierwszego tysiąclecia „Michał Archanioł powszechnie był czczony jako patron ludzi słabych i chorych, zdanych na pomoc Bożą. Zwiastunem zaś i jakby wyrazicielem mocy Bożej - zgodnie z przekazem biblijnym - jest właśnie ów Książę Bożych posłańców. Dlatego świątynie pod jego wezwaniem stawiano obok cudownych źródeł czy sadzawek, mających uzdrawiającą moc"40.

W chrześcijańskiej ikonologii siły anielskie są reprezentowane w estetycznie doskonałych postaciach, w przeciwieństwie do potworności sił zła. Michał Archanioł jest przedstawiany jako napełniony siłą. To postać pięknego, młodego wodza wojsk niebiańskich. Ten wojownik reprezentuje nie tylko pełnię sił fizycznych. Jego postać to nośnik pewnej postawy duchowej. Takie wyobrażenie Archanioła symbolizuje majestat i piękno Królestwa Niebieskiego. Jednocześnie obrazy szatana, upadłych aniołów i grzeszników

\footnotetext{
${ }^{38}$ „Judica Sunday”, dostęp 15.06.2021, https://www.newadvent.org/cathen/08553a.htm.

${ }^{39}$ Gotik. Architektur. Sculptur. Malerei (H.F. Ullmann, 2009), 310-312.

${ }^{40}$ Jan Mazur OSPPE, „Skałka na przełomie tysiącleci”, Peregrinus Cracoviensis 14(2003): 16.
} 
kontrastują wizualnie z osobą Archanioła. Malarze starali się przekazać brzydotę zła poprzez niekształtne ukazanie postaci budzące odrazę i strach. Nie bez znaczenia pozostawały także nienaturalne pozycje ciał. Jako przykład można przywołać chociażby obraz Świętego Michała autorstwa Juana de la Abadía el Viejo (Museu Nacional d'Art de Catalunya, Barselona). W artystycznej wizji posłaniec Boga nie tylko epatuje pięknem zewnętrznym, górując nad szpetotą świata złych duchów. Dokonuje on także sądowniczego ważenia duszy człowieka ${ }^{41}$.

Obraz Sądu Ostatecznego wraz z towarzyszącą mu symboliką, zaczerpniętą z Objawienia, od wieków stanowił inspirację dla sztuki sakralnej. W działalności twórców chodziło o przekaz niezmiennych idei, jakie dotyczyły sprawiedliwości, której źródłem jest sam Bóg. Symbolika, związana ze sprawami ostatecznymi, znalazła także swoje szczególne miejsce w wyobrażeniach sądów świeckich. Obraz Sądu Ostatecznego jest zatem (jak starano się to zaprezentować) podstawą interesującego dyskursu intelektualnego. Łączy bowiem w sobie przestrzeń teologii chrześcijańskiej i sądownictwa w realizacji jednego wspólnego celu - ustanowienia idei wyższej sprawiedliwości, której nikt nie może uniknąć w obliczu sądu Bożego (chrześcijaństwo) oraz praworządności i sprawiedliwego bezstronnego sądu (w zakresie jurysdykcji świeckiego sądownictwa).

\section{BIBLIOGRAFIA}

Адамчик, Владимир, авт-сост.. Словарь символов и знаков. Москва: АСТ; Минск: Харвест [Adamchik, Vladimir V., avt.-sost., Slovar' simvolov i znakov. Moskva: AST; Minsk: Kharvest], 2006.

Бальтазар, Ганс Урс фон. „Суды Божии в Откровении Иоанна Богослова”. W: Символ, [Balthasar, Hans Urs von. „Sudy Bozhii v Otkrovenii Ioanna Bogoslova”. V: Simvol], Paris 16(1986): 9-17.

Bardski, Krzysztof ks. „Bóg jako sprawiedliwy sędzia w symbolicznej ikonosferze biblijnej starożytności chrześcijańskiej i średniowiecza". Verbum Vitae 26(2014):143-157. Dostęp 10.07. 2021. http://cejsh.icm.edu.pl/cejsh/element/bwmeta1.element.desklight-45d01e1e-1d01-442590d4-49b0d4bf0949/c/143_pdfsam_Verbum_26.pdf.

${ }^{41}$ Juan de la Abadía (the Elder), „Saint Michael Weighing Souls”, dostęp 15.06.2021, https:// www.museunacional.cat/en/colleccio/saint-michael-weighing-souls/juan-de-la-abadia-el-vell/0050 82-000. 
Chomyn, Igor. 150 arcydziet malarstwa polskiego ze zbiorów Lwowskiej Galerii Sztuki. Pelplin: Bernardinum, 2006.

Codex Iuris Canonici. Poznań: Pallotinum, 1984.

Dobrzeniecki, Karol. „Harmonia teologii, prawa i kosmologii na przykładach zastosowania motywu wagi w sztuce czasów przednowożytnych”. Teologia i człowiek. Kwartalnik Wydziału Teologicznego UMK 30(2015), 2: 79-93.

Егоров, Алексей. „Кризисы в истории Рима (события и проблемы)”. W: Мнемон. Исследования и публикачии по истории античного мира. Сборник статей к 80-летию со дня рождения проф. Э.Д. Фролова. СПб. [Yegorov, Aleksey B. „Krizisy v istorii Rima (sobytiia i problemy)". V: Mnemon. Issledovania i publikatsyi po istorii antichnogo mira. Sbornik statei k 80-letiu so dnia rozhdenia prof. E.D.Frolova. SPb.], 12(2013): 346-365.

Еко, Умберто, ред., Історія європейської ичиілізаиії. Середньовіччя. Варвари. Християни. Мусульмани; пер. $з$ італ. Харків: Фоліо [Eco, Umberto, red., Istoria evropeiskoi tsyvilizatsii. Seredniovichia. Varvary. Khrystyiany. Musul'many; per. z ital. Kharkiv: Folio], 2018.

Еко, Умберто, ред., Історія європейської ичивілізаиії. Середньовіччя. Собори. Лицарі. Місma; пер. $з$ італ. Харків: Фоліо [Eco, Umberto, red., Istoria evropeiskoi tsyvilizatsii. Seredniovichia. Sobory. Lytsari. Mista; per. z ital. Kharkiv: Folio], 2018.

Forstner, Dorothea OSB. Świat symboliki chrześcijańskiej. Leksykon. Warszawa: PAX, 2001.

Георгиевский, Эдуард. „Символизм древнерусского уголовного права”. Право и политика [Georgievskiy, Eduard V. „Simvolizm drevnerusskogo ugolovnogo prava”. Pravo i politika] 2(2013): 238-248.

Gotik. Architektur. Sculptur. Malerei. H.F. Ullmann, 2009.

Greek-English New Testament. Deutsche Bibelgesellschaft, 1998.

Губаева, Тамара. Язык и право. Искусство владения словом в профессиональной юридической деятельности. 2-е изд., пересмотр. Москва: Норма: Инфра-М [Gubaeva, Tamara. Iazyk i pravo. Iskusstvo vladeniia slovom v professional'noi iuridicheskoi deiatel'nosti. 2-e izd., peresmotr. Moskva: Norma: Infra-M], 2010.

Гуревич, Арон. Избранные труды. Культура средневековой Европы. Санкт-Петербург: Изд-во С.-Петербургского у-та [Gurevich, Aron Y. Izbrannye trudy. Kul'tura srednevekovoi Evropy. Sankt-Peterburg: Izd-vo S.-Peterburgskogo u-ta], 2006.

Howes, Llewellyn. „Who Will Put My Soul on the Scale?: Psychostasia in Second Temple Judaism". Old Testament Essays 27(2014), 1: 100-122.

Григорак, Анастасія. Світоглядні орієнтири українського соціуму у світлі іконографії Страшного суду XV-XVIII ст. Автореф. дисерт. ... к. іст. н. Київ [Hryhorak, Anastasia K. Svitohladni orientyry ukrains'koho sotsiumu u svitli ikonografii Strashnoho sudu XV-XVIII st. Autoref. dysert. ... k. ist. n. Kyiv], 2020.

Juan de la Abadía (the Elder). „Saint Michael Weighing Souls”. Dostęp 15.06.2021. https:// www.museunacional.cat/en/colleccio/saint-michael-weighing-souls/juan-de-la-abadia-el-vell/ 005082-000.

Judica Sunday. Dostęp 15.06.2021. https://www.newadvent.org/cathen/08553a.htm.

Катехизм Католицької Церкви. Синод Украӥнської Греко-Католицької Церкви [Каtekhyzт Katolyts 'koi Tserkvy. Synod Ukrains'koi Hreko-katolyts 'koi Tserkvy], 2002.

La Cappella degli Scrovegni. Dostęp 15.06.2021. http://www.cappelladegliscrovegni.it/index. php/it/. 
Mazur, Jan OSPPE. „Skałka na przełomie tysiącleci”. Peregrinus Cracoviensis 14(2003): 13-35.

Мелетинский, Елеазар, гл. ред., Мифологический словарь. Москва: Сов. Энциклопедия [Meletinskii, Eleazar M., gl. red., Mifologicheskii slovar'. Moskva: Sov. Entsyklopedia], 1990.

Мень, Олександр. Проповіді на церковний рік; пер. з рос. М. Лемик. Львів: Свічадо, [Mеn, Oleksandr. Propovidi na tserkovnyi rik; per. z ros. M. Lemyk. L’viv: Svichado] 2014.

Novum Testamentum Latine. Deutsche Bibelgesellschaft, 2002.

О’Грейді, Джон Ф. „Современное состояние христологии”. W: Современное католическое богословие. Хрестоматия, пер. с англ., 201-231. Москва: ББИ св. апостола Андрея [O'Grady, John F. „Sovremennoe sostoianie khristologii”. V: Sovremennoe katolicheskoe bogoslovie. Khrestomatia, per. s angl., 201-231. Moskva: BBI sv. apostola Andreia], 2007.

Пальцева, Лариса. „Судебные институты архаической Греции”. W: Мнемон. Исследования и публикации по истории античного мира. Санкт-Петербург [Pal'tseva, Larisa A. „Sudebnye instituty arkhaicheskoi Gretsii". V: Mnemon. Issledovania i publikastyi po istorii antichnogo mira. Sankt-Peterburg], 7(2008): 85-96.

Райкен, Лиланд, и др., ред. Словарь библейских образов; пер. с англ. Санкт-Петербург: Библия для всех [Ryken, Leland, i dr., red. Slovar' bibleiskikh obrazov, per. s angl. Sankt-Peterburg: Biblia dla vsekh], 2008.

Телицын, Вадим, ред. Символы, знаки, эмблемы: Энциклопедия. Москва: ЛОКИД-ПРЕСС: РИПОЛ Классик [Telitsyn, Vadim L., red. Simvoly, znaki, emblemy: Entsyklopedia. Moskva: LOKID-PRESS: RIPOL Klassik], 2005.

Власова, Галина. Легитимация институтов публичной власти в политико-правовом и социокультурном измерениях (на примере эволюции правосудия). Автореф. дисс. ... д. ю.н. Ростов-на-Дону [Vlasova, Galina В. Legitimatsyia institutov publichnoi vlasti v politicopravovom i sotsyokul'turnom izmereniiakh (na primere evolutsii pravosudia). Avtoref. diss. ... d. iur. n. Rostov-na-Donu], 2009.

\section{OBRAZ SĄDU OSTATECZNEGO W IKONOSFERZE SĄDOWNICTWA}

\section{Streszczenie}

Główną funkcją tematyki sądowej w sztuce jest prezentacja wartości i sprawiedliwości. Niniejszy artykuł omawia zagadnienie dialogu prawa, religii i sztuki na przykładzie obrazu Sądu Ostatecznego, który ukazuje idę̨ wyższej sprawiedliwości, usankcjonowanej przez Boga jako Najwyższego Sędziego. W oparciu o porównawczo-historyczną, semiotyczną i hermeneutyczną metodę wyodrębniono kwestię genezy i istoty chrześcijańskiej idei Sądu Ostatecznego na podstawie narracji mitów egipskich i starogreckich oraz tekstów Pisma Świętego. Badane są główne obrazy i symbole tego wątku, a mianowicie: Chrystus Sędzia, św. Michał, waga i psychostazja. Podano przykłady Sądu Ostatecznego w ikonografii kościelnej i w sztuce.

Słowa kluczowe: Sąd Ostateczny; Chrystus Sędzia; ikonosfera sądownictwa; symbolika sądowa. 